\title{
Influence of polyphenol-rich apple pomace extract on oxidative damage to DNA in type 2 diabetes mellitus individuals
}

\author{
Annemarie Grindel ${ }^{1 *}$, Elisabeth Müllner ${ }^{1}$, Helmut Brath ${ }^{2}$, Walther Jäger ${ }^{3}$, Trine Henriksen ${ }^{4,5}$, \\ Henrik Enghusen Poulsen ${ }^{5,6}$, Doris Marko ${ }^{7}$, Karl-Heinz Wagner ${ }^{1}$ \\ From Metabolism, Diet and Disease 2014: Cancer and metabolism \\ Washington DC, USA. 28-30 May 2014
}

\section{Background}

Diabetes mellitus type 2 (DM2) is associated with increased oxidative stress and oxidative damage to DNA. An appropriate intake of antioxidants via the diet can improve this disturbed oxidative status [1]. Apples are the most widely consumed fruits in Europe and represent a major source of antioxidants due to their high polyphenol content [2]. Apple pomace as a polyphenol-rich byproduct of apple juice production could serve as a cheap and reliable tool for a nutraceutical with antioxidative properties.

\section{Materials and methods}

To test the antioxidant potential of a pectin-depleted apple pomace extract (APE) in human subjects, a placebo-controlled, crossover, double-blind, pilot human intervention study was performed. Eighteen postmenopausal women with DM2 (age $=69.7 \pm 6.7 \mathrm{y} ; \mathrm{BMI}=33.9 \pm 4.5 \mathrm{~kg} / \mathrm{m} 2)$ were randomly allocated to receive either APE (440 mg per capsule containing about $100 \mathrm{mg}$ total polyphenols, once daily) or placebo during two 4-week supplementation periods separated by a 4-week wash-out period. Before and after each supplementation period oxidative damage to DNA (Comet Assay) in peripheral blood mononuclear cells (PBMC) and whole blood, urinary excretion of 8oxo-7hydro-2'-deoxyguanosine (8-oxodG) and 8-oxo-7,8dihydroguanosine (8-oxoGuo), glycated hemoglobin (HbA1c), fasting blood glucose, insulin, C-peptide and anthropometric indices were measured. The bioavailability of the main APE polyphenol Phloridzin and its metabolite Phloretin were analyzed in plasma samples.

${ }^{1}$ Department of Nutritional Sciences, University of Vienna, Vienna, Austria Full list of author information is available at the end of the article

\section{Results}

In contrast to the placebo-supplementation, APE resulted in detectable plasma Phloridzin $(12.7 \pm 40.7 \mathrm{ng} / \mathrm{ml})$ and Phloretin $(19.3 \pm 36.5 \mathrm{ng} / \mathrm{ml})$ concentrations. The study population was characterized by HbA1c $=54.9 \pm 6.3 \mathrm{mmol} /$ $\mathrm{mol}$, fasting blood glucose $=8.1 \pm 1.9 \mathrm{mmol} / \mathrm{l}$, fasting insulin $=99.3 \pm 36.6 \mathrm{pmol} / \mathrm{l}$ and $\mathrm{C}$-peptide $=1.3 \pm 0.4 \mathrm{nmol} / \mathrm{l}$ baseline levels. However, these DM2 biomarkers were not influenced by the supplementation with APE compared to placebo. No changes occurred in 8-oxoGuo and 8-oxodG. FPG-sensitive sites of whole blood decreased $(P=0.026)$ regarding apple pomace intervention of both diet periods. Neither DNA strand breaks nor $\mathrm{H}_{2} \mathrm{O}_{2}$-sensitivity of DNA altered following APE supplementation.

\section{Conclusions}

Oxidatively damaged purines decreased after APE intervention while other markers of oxidative damage to DNA in DM2 individuals did not change after short-term supplementation with polyphenol-rich APE.

\begin{abstract}
Authors' details
${ }^{1}$ Department of Nutritional Sciences, University of Vienna, Vienna, Austria. ${ }^{2}$ Diabetes Outpatient Clinic, Health Centre South, Vienna, Austria.

${ }^{3}$ Department of Clinical Pharmacy and Diagnostics, University of Vienna, Vienna, Austria. ${ }^{4}$ Laboratory of Clinical Pharmacology, Rigshospitalet, Copenhagen, Denmark. ${ }^{5}$ Department of Clinical Pharmacology, Bispebjerg Hospital, Copenhagen, Denmark. ${ }^{6}$ Health Science Faculty, University of Copenhagen, Copenhagen, Denmark. ${ }^{7}$ Institute of Food Chemistry and Toxicology, University of Vienna, Vienna, Austria.
\end{abstract}

Published: 28 May 2014

\section{References \\ 1. Müllner E, Brath H, Pleifer S, Schiermayr C, Baierl A, Wallner M, Fastian T, Millner $\mathrm{Y}$, Paller $\mathrm{K}$, Henriksen $\mathrm{T}$, Poulsen HE, Forster $\mathrm{E}$, Wagner $\mathrm{KH}$ :}


Vegetables and PUFA-rich plant oil reduce DNA strand breaks in individuals with type 2 diabetes. Mol Nutr Food Res 2013, 57:328-338.

2. Hyson DA: A comprehensive review of apples and apple components and their relationship to human health. Adv Nutr 2011, 2:408-420.

doi:10.1186/2049-3002-2-S1-P25

Cite this article as: Grindel et al:: Influence of polyphenol-rich apple pomace extract on oxidative damage to DNA in type 2 diabetes mellitus individuals. Cancer \& Metabolism 2014 2(Suppl 1):P25.

Submit your next manuscript to BioMed Central and take full advantage of:

- Convenient online submission

- Thorough peer review

- No space constraints or color figure charges

- Immediate publication on acceptance

- Inclusion in PubMed, CAS, Scopus and Google Scholar

- Research which is freely available for redistribution

Submit your manuscript at www.biomedcentral.com/submit
C Biomed Central 